\title{
TOURISM DEVELOPMENT OF THE ARCHAEOLOGICAL AREAS AND THEIR CRAFTSMANSHIP IN THE ARCHAEOLOGICAL AREA OF THE RADWAN KASBAH
}

Haidi Ahmed Musa GHALEB *

Ministry of Tourism and Antiquities, Egypt

\begin{abstract}
The areas of archaeological value receive great attention as they are the oldest areas in the city, as they form the beating heart that records the history of the city and its features through various successive historical and political eras. Its inhabitants and its trades and activities. The archaeological and heritage areas take on their importance through a set of aesthetic, architectural, functional and historical values, in addition to social, investment and economic values, as the archaeological area contains a large group of historical buildings dating back to different eras with wealth belonging to mankind. About the memory of the place in addition to its being the continuous culture, especially the elements that are preserved and preserved in the built environment, and the cultural heritage is a major.

Keywords

Tourism Development, Archaeological Areas, Craftsmanship, Radwan Kasbah.
\end{abstract}

\section{Introduction}

Component of the heritage area, and it includes the following: Features of the natural environment and traditional life, Historical buildings, facilities and sites, Special events such as celebrations, events and handicrafts, the Armenian artisan community is also considered one of the components of the human heritage. Artisan products are nothing but a product of the influence of a group of social, cultural, economic and political factors that fuse together into a single urban melting pot that emanates from and expresses it.

\section{First: The archaeological area of the Radwan Kasbah:}

- The originator of this qasbah is Prince Radwan Bey bin Abd Allah al-Fiqari, the prince of the Egyptian Hajj of Karaj in origin, he was one of the Mamluks of Prince Zulfiqar Bey, this prince took care of building the good monuments on the Egyptian Hajj Road, and during his leadership of the Hajj he presented his trials When the order came to him to isolate him from this emirate, Sultan Murad ordered his imprisonment and sale of his property, and he remained imprisoned until the Sultan died. He was subjected to many trials until he died without his offspring, and was buried in his soil in the Imam al-Shafi'i, so many were arrested for his release and many of Land destinations.

\footnotetext{
*Corresponding author: haidimg@gmail.com
} 
The Radwan Kasbah in Cairo is considered the great archaeological market that represents the main part of the group of facilities built by Radwan Bey in the year 1060 AH / 1650AD, directly south of Bab Zuwaila, to simulate the Fatimid Kasbah of Cairo, which is known today as AlMuizz Street and made it a roundabout, a corner, a seat It also established the other angle which sailors Qurbiyyah.

As for the markets in general, they are considered the main reason for the existence of the population gathering, as they are the main part of the city, and this market of Khiamiyah is one of the stable markets in certain stores throughout the year, visited by those who want to be supplied with the goods and materials they need, and the markets used to play a large role How much emphasis is placed on trade and cultural exchange between the population, and therefore the markets are among the most prominent elements of Oman that should be preserved and the crafts that are present in them, as part of an integrated policy to preserve the archaeological and heritage sites. Ibn Sidh said the market, saying: "The market is derived from the market of people for their goods. It is mentioned and feminine, and the plural markets are, as al-Maqrizi defines the market, saying: "The Kasbah of the country is his city, and most of it was said, and the Kasbah is the greatest market in Egypt.

The Kasbah Radwan or Khayameya Street is located in front of Bab Zwaila near the area of Taht al-Rab'a, the first of which is Bab al-Mutawali and the end of it is al-Dawudiyah Street, and the building of the Qasaba Radwan Market is a rectangular corridor covered with a roof of wooden veins applied with transverse panels with nineteen openings for ventilation and lighting, lined up on both sides of the street A group of shops are stacked next to each other, often with an area of about $3 \times 2$ meters or a little larger, representing the tents workshops topped by the houses of Radwan Bey.These shops include a variety of crafts, including those specialized in making and selling shoes and slippers, the middle of which is known as Khayamiyyah, the last of which is known as Gharibin.

Khayameya: Souad Maher defined this type of embroidery as: "Adding small pieces of fabric to a large area of different color and often in the material, by sewing it with a sewing needle and with different stitches, and this addition occurs in a beautiful shape or decorative element, and this is known The method of embroidering in Egypt with the name of the tent work, in Turkey with the name of the sarmah work, and in Iran by the name of the calfidon or Rasht, but in Europe the names of this method have multiplied by the multiplicity of the decorative form, it is known as the added decoration applied and is known as the reserved technique or patch work, but if the cut The additive is very small, next to each other and multi-colored, and 
is known as the mosaic, and the added pieces are often accompanied by multiple stitches, which are suitable for decoration and output of shapes and general scenes.

This and Khayameya is a handicraft known since the dawn of history. The first known attempt to decorate textiles by the method of addition goes back to the ancient Egyptians, to give it an aesthetic character, and in the Coptic period I found many examples of added weaving.

Ibn Khaldun also mentioned it in his introduction, saying: "It is among the king's insignia and luxury to take khubiyat, rugs and vases from linen garments, wool and cotton. Linen and cotton are interwoven and flaunted in travels, and the colors vary from large and small to the proportion of the state in wealth and left, and the Arabs were During the era of the first caliphs who built illiteracy, they inhabited their houses, which had tents of fluff and wool, and from the tents also known the rank of pilgrims, and when the Arab state mastered the manifestations of civilization and extravagance, and they camped cities and cities and moved from the tents to the palaces, they used to dwell in linen as their travels Some of them are homes of various shapes that are capable of proverbs of recitation, rectangular and square, and they celebrate in them the most eloquent doctrines of celebration and adornment.

Among the most famous tents that were also mentioned was the tent of Qatr al-Nada, the daughter of Khmaruyeh in the Tulunid era, as al-Maqrizi mentioned in his plans for tents in the Fatimid era, saying: Deeqa, velvet, kosherwani, royal brocade, and the like of all its colors and types, as well as the muffle, the septa, the imagination, the twin, the rainbow, and other such beasts, birds, and human beings from all other wonderful and ingenious shapes and images.

Tents were also of great importance in the Ayyubid era, especially in travel, as it was an era of wars, camps, and many transfers, and they had experienced brushes who used their mattresses and prepared them in the best way, and they called the bed Khanah, and the tent flourished more in the Mamluk era, where the tents and the tents flourished more. In the Ottoman era, it was mentioned that the bonds were established extensively in the celebration of the Noble Prophet's birthday in the Birkat al-Azbakeya area, where the saqs were filled with rings of dhikr

In the nineteenth and twentieth centuries, Ahmed Amin remembers saying: "If there was a great joy or a funeral, a granite was erected according to the size of its owner. Then the colored tents were installed in white and red from the inside, and they were roofed with tents in the winter, so the manufacture and use of tents continues to this day. 


\section{How to make the tent:}

\section{A- Maker session:}

The Usta sits on a wooden bench, and the bench is often clad and furnished with kilims, and some of them sit with a basket of cotton under it, each one according to his comfort, because the working conditions require that the tents sit for long hours, and the two tents have a special way of sitting where they raise a leg and bend another most of the time It is called (Qada alKhayyat) and it is usually a difficult session for those who are not accustomed to it, and there is another session called Rabi'a which is for women, and if in our present time they sit on a table through which they make tent products

\section{B- The work system inside the workshop:}

The work system is based on the teacher or the Usta, and he is the owner of the workshop or the industrialist who is called (tent hand), and he is the one who carries out the manufacturing process, and with him a boy or two to handle the demands of the Usta and to teach them the craft as well, and there are some workshops that depend on a factory. They follow them, whether they work in their homes or in workshops far from the Khayameya neighborhood.

\section{C- The calculation system inside the workshop:}

The owner of the industrial workshop is held accountable in several ways, either by piece, or by the fact that the industrialist works for a wage by the day or by the week, and there are those who are held accountable with the workshop by leaving, so leaving the lux has an account and the custom leaving has another account.

\section{D) Raw materials and tools used in the workshop- :}

\section{First: raw materials:}

Fabric: composite sailing fabrics (duck and salmut) are used as a lining or flooring for the tent to be executed, and other fabrics are added to it such as (truklin - polin - batiste - dacron - satin - fatteh - silk), but with the emergence of other types of fabrics, we have become Now we use fabrics with a large percentage of polyester, which are distinguished from cotton fabrics by the stability of their colors, and yet they are harmful to work as it is difficult to penetrate the needle to some of these fabrics, and the needle makes an effect on these fabrics. Threads: In the past, the tents used cotton threads, but they faded, and polyester threads have now replaced them. Noir tape: It is a ribbon of Arab cotton cloth that is sewn on Turkish letters, as an external frame that governs and defines the drawing. Paper that is used as an iron: it is sheets of paper called parcel paper, it has a dark beige color that allows the necessary designs to be drawn on it, and it is thick so that it can withstand scratching on it, that is, perforating, after the design is implemented on it it is called parcel paper, and the drawings are transferred from the walls of 
the mosques or the drawings of the mosques. Landscapes, and these origins of drawings are called (styles). Needles: It is a group of needles used for sewing tents, including what is used for scratching, and working the needle is the most important thing in this craft, to make magic stitches, and the needles are sizes and the basic one of them is No. 6.5, while the large needles called the locket needle are used for scratching only There is also an obelisk or tent needle, which is used for sewing a thick turk. Castpan: It is a small metal part that resembles a fez, with small frames called manayem, whose task is to thin the needle and help it In sister, thin the cloth, and to protect the manufacturer's fingers. Dusty: It is a bag of cloth that is filled with crushed coal dust if the cloth is white, or with talcum powder if the cloth is black, and it is dusted, meaning that the painting is knocked out after being scratched or perforated. As well as some other tools such as pencils, scissors, dusters, a ruler and a board.

\section{Third: The stages involved in the manufacturing process- :}

- The stage of determining the drawing styles.

- Screaming stage.

- The soil stage.

- The stage of determining the drawing in pencil.

- The stage of identifying the colors in the drawing.

- The sewing stage.

- Determination and underline stage.

- The stage of installing the final frame.

The work begins by selecting the stems from which the subject will be transferred, then drawing the design on the iron by scribbling it, then the floor cloth is brought and it is called the body, then they are fixed on the board, and the specialized powder (soil) is spread on the iron after placing it on top of the cloth, then the drawing is determined by pencil until The drawing is completed, then the appropriate colors are chosen for the drawing, then start to cut each part of the drawing according to the chosen color, then the edges of the cut cloth are bended and sewn with magic stitches, then the final shape is determined, and then the final frame is installed.

\section{How to preserve the archaeological area, and develop its surrounding and upgrading- :}

Tourism is a human dialogue between people and civilizations that highlights the true image of the state and contributes to preserving the historical and cultural heritage in it, and in order for us to achieve the preservation of the state's identity and heritage, an important question must come to our minds: 


\section{Why do we preserve archaeological and heritage areas?}

-Historical reasons: Every stone tells us the periods, events and personalities that went through it, lived with it and coexisted with it, and melted with it in one melting pot, where the distinctive architectural and artistic elements, traditional crafts, customs, traditions and heritage of the region are factors that attract visitors.

-Economic reasons: it is one of the most important sources of national income for countries.

-Social reasons: in terms of memories and events that these places tell us about those who lived in them at different times, the extent of their position in society, their culture, their progress and their sophistication in construction and decoration through the building's rich architectural and technical elements, providing job opportunities for the people of the region.

-Religious reasons: as Islamic architecture is linked to the jurisprudence of Islam in construction, as well as the existence of religious structures such as the zawiya that was established by Prince Radwan, and endowments that were used to dispose of these religious places to ensure that it continues to perform its religious role, so the Kasbah of Radwan is an endowment, It also explains the road network in the Islamic city, and how to choose the location of the markets also in these cities.

Political reasons: These are evident through the place where women in the Ottoman era chose to live near the castle, the seat of government at the time.

-Cultural reasons: These areas form a cultural awareness for the visitor in the artistic, aesthetic, archaeological, political and historical aspects, as the market is a mirror of social and historical events as it is the expression of traditions and customs, and the market is also a source of social interaction during the different historical eras that it has gone through, this and the market. My legacy in the Radwan Kasbah is the inheritance of various activities, as it displays the handicraft goods and products that visitors from all over the world come to see ancient crafts, and the exquisite handicrafts and own them.

-Aesthetic artistic reasons: which is reflected in the architecture of the Kasbah of Radwan, as it is one of the covered markets, in addition to the skill of the architectural construction and the few remaining decorative elements.

\section{Results:}

-There must be a scientific methodology and a conscious management that understands the nature of the heritage sites when managing them, taking into account the conditions, traditions and social, economic and political conditions prevailing in the community who owns this heritage, especially since there has been a near-halt to the tourism movement after the revolution of January 25, 2011, as the region suffers from economic stagnation as a result of 
political events The country has passed through, and there is a need for an administrative database that provides effective solutions to manage these sites and protect them from the causes of damage and destruction, as well as protect the craft of tents from extinction, and the financial and human resources required by this administration, that achieve successful management.

\section{Recommendations:}

1- The concerned and responsible authorities shall join together and sign cooperation protocols between them, as the Ministry of Antiquities, the Ministry of Tourism, the Ministry of Culture, the Ministry of Environment, the Ministry of Endowments, the Ministry of Interior, the Ministry of Foreign Affairs and Information.

2-Setting short and long-term plans for managing the archaeological site, setting a specific timetable for the implementation of these plans, and clearly defining the terms of reference of each party participating in these plans, to avoid conflicts of jurisdiction.

3-The effectiveness of implementing these plans and programs on the ground, according to the timetable set in advance.

4-Providing the necessary financial resources.

5-Providing the necessary administrative, technical and technical expertise for this.

6-Providing places to wait for tourist buses, and providing golf carts to move within the area for free, similar to Al-Muizz Street.

7-Creating a visit path that shows visitors their route, as well as making travel leaflets that show the most important archaeological landmarks and heritage crafts in the region.

8-Making identification panels at the beginning and end of the area, as well as at each monument or heritage building, to show its most important features and its artistic, historical and archaeological values, provided that they are in the Arabic and English languages, and are made of materials that bear various environmental factors.

9-Providing places to rest for the elderly, as well as providing cafeterias that serve popular Egyptian food and be decorated with heritage décor, with teams presenting traditional Egyptian folk arts, as well as providing money exchange offices for currency exchange and machines for automatic exchange.

10-Re-use of the houses of the Radwan Kasbah, which were restored nearly ten years ago, and have been closed since that time, by making it a heritage tourist hotel for the stay of visitors in the heart of the historic city, as well as vacating the Radwan seat of the residents who lived in it after compensating them with suitable compensation and a comprehensive restoration. And to be precise, and use it as an exhibition to see visitors the stages of making the tents throughout 
history, and also part of it is used as a visitors' center through which a short documentary film about the history of the region and its handicrafts is shown, and the rest of the demolished part of the houses is employed after it is restored as a cafeteria.

11-Holding internal and external exhibitions for the products of the tent craft, while providing full media propaganda to promote this heritage area and its important crafts.

Moreover, if the archaeological site is managed properly, it will result in many of the previously mentioned social, economic, tourist and cultural benefits.

\section{References:}

1- ابن خلدون، ولى الدين عبد الرحمن بن محمد، ت:^ • ^ه، مقدمة ابن خلدون، تحقيق: عبد الله محمد الدرويش، طا،

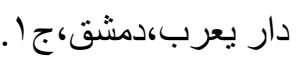
2- ابن سيده،أبى الحسن على بن إسماعيل النحوى اللغوى الأندلسى،ت: بيروت،د.ت، جنا 3- القلتشندى، أبى العباس أحمد،صبح الأعشى فى صناعة الأنشاءد.ط،المطبعةالأمبرية،القاهرة،

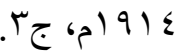

4- المقريزى، تقى الدين أحمد بن على،ت:0ـ ^ه،المو اعظو الأعتبار بذكر الخططو الأثار،الطبعة الأولى ، مكتبة مدبولى،

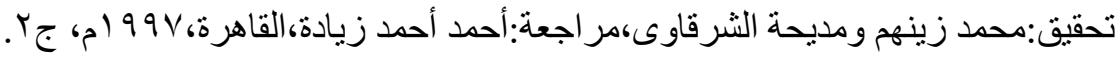

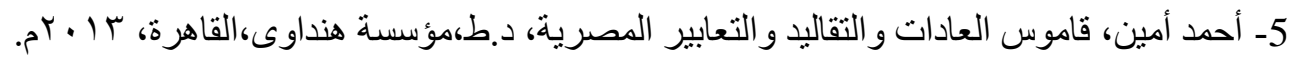
6- سعاد ماهر محمد، الفنون الإسلامية،د.ط،الهيئة المصرية العامة للكتاب، القاهرة، ب . . بم.

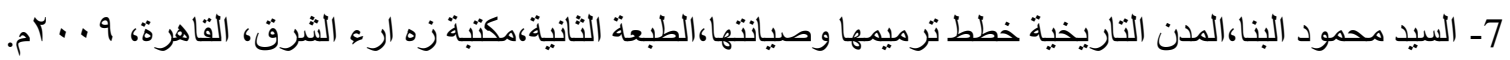
8- عاصم محمد رزق، أطلس العمارة الإسلامية و القبطية بالقاهرة، طا ، مكتبة مدبولى، القاهرة، (

9ـ محمد دسوقى، الثموع و الفو انيس و الخيامية فى حى الدرب الأحمر، د.ط، الهيئة العامة لقصور الثقافة،القاهرة ، 9 ـ . ب م.

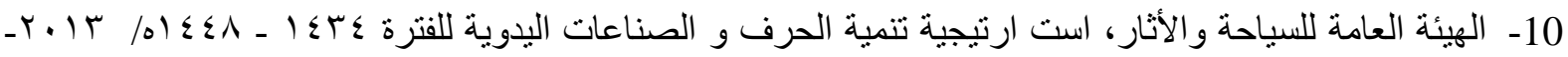

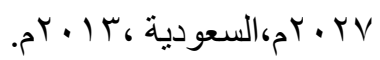
11- اوارنس عبد الواحد علوان، الحفاظ على الأسواق التراثية ضمن اطار عمل متكامل للحفاظ على الموروث العم ارنى

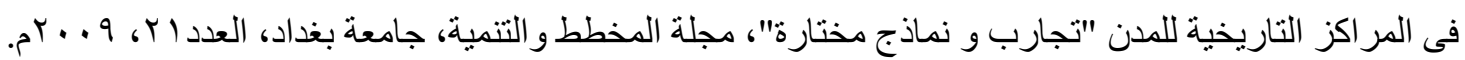
12- السيد محمود البنا، بعض معايير إعادة الإستخدام أو التأهيل للمبانى الأثرية التى نوقف إستخدامهاهمجلة كلية الآداب

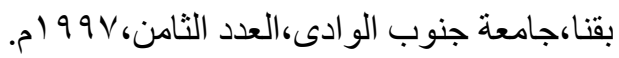
13- فايز الديب و عمر خليل ،توثيق المنشأت الأثرية بإستخدام النماذج ثلاثية الأبعاد متعددة الصور، مجلة جامعة دمثق

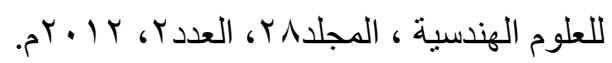
14- قدرية نوكل البندارى، الحرف التقايدية فى مصر"فن صناعة الخيامية فى مصر"، المؤتمر السادس عشر للآثاريين

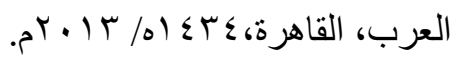


15- ر غد مفيد محمد إبر اهيم، ثقافة المجتمعات و عمر ان المناطق ذات القيمة التر اثية" د ارسة فى نأثير التغير ات الثقافية

و الإجتماعية على التشكيل العم ارنى"هخطوط ماجستير غير منشورة، قهم الهندسة المعمارية، كلية

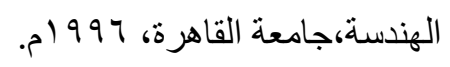

16- عبد الله محمد لطفى عبد الله، در اسة تحليلية لخصائص المجتمعات الحرفية التجارية فى العو اصم المصرية فى العصور الوسطى الإسلامية من الفتح العربى وحتى الفتح العثمانى، مخطوط ماجستير غير منشورة، قسم التخطبط الإقليمى و العمر انى كلية الهندسة،جامعة القاهرة، ع 99 (م. 17- مها محمد عز الدين حنفى، التنمية السياحية المستدامة للأسواق النراثية فى المناطق التاريخية بإستخدام مؤشرات الإستدامة ، مخطوط ماجستير غير منشورة ، قسم التصميم العمر انى، كلية التخطيط العمر انى و الإ قليمى، جامعة القاهرة، 